\section{Optic nerve head blood flow measurements in non-arteritic anterior ischaemic optic neuropathy}

HANA LEIBA, RONY RACHMIEL, ALON HARRIS, LARRY KAGEMANN, AYALA POLLACK, MIRIAM ZALISH
H. Leiba

R. Rachmiel

A. Pollack

M. Zalish

Ophthalmology Department Kaplan Medical Center Rehovot, Israel

\section{A. Harris}

L. Kagemann

Glaucoma Research and

Diagnostic Center

Indiana University School of

Medicine

Indianapolis

Indiana, USA

Hana Leiba, MD

Department of

Ophthalmology

Kaplan Medical Center

76100 Rehovot, Israel

Tel: +972 89441353

Fax: +97289441821

Presented as a poster at the International Congress of

Ophthalmology,

Amsterdam, The

Netherlands, 21-26 June

1998, and at ARVO, Florida,

USA, 9-14 May 1999, and

as a paper at the European

Neuroophthalmological

Society Meeting, Jerusalem, Israel, 31 August-2

September 1999

Received: 27 March 1999 Accepted in revised form: 14 July 2000

\begin{abstract}
Purpose To determine whether a decrease in blood flow, measured by the Heidelberg retiinal flowmeter, can characterise a disc at risk and predict the occurrence of non-arteritic anterior ischaemic optic neuropathy (NAION). Methods Blood flow, volume and velocity were measured in the optic nerve heads of 14 unaffected fellow eyes of patients with unilateral NAION, and compared with those of the affected eyes and of the eyes of 7 agematched healthy controls.

Results The affected eyes were found to differ from the unaffected eyes in all three haemodynamic parameters. Flow (measured in arbitrary units) is the most important parameter to be taken into consideration. Blood flow was significantly lower in affected than in unaffected eyes (upper rim, $p<0.05$; lower rim, $p<0.025$ ). It was also significantly lower in the unaffected eyes than in the healthy control eyes $(p<0.005$, upper and lower rims), and in the affected eyes than in the control eyes $(p<0.00005$, upper and lower rims).

Conclusion Decreased blood flow in the optic nerve head may indicate a risk for NAION and be considered a characteristic of the disc at risk.
\end{abstract}

Key words Anterior ischaemic optic neuropathy, Blood flow

Non-arteritic ischaemic optic neuropathy (NAION) is one of the most prevalent and visually crippling disease of the middle-aged and elderly. ${ }^{1}$ The pathogenesis of NAION is not clearly understood but is probably related to reduced perfusion of the optic nerve head below some critical level. ${ }^{1}$

Many risk factors for the development of NAION and indices for its prediction have been proposed. They include diabetes mellitus, systemic hypertension, hypercholesterolaemia, coronary heart disease, chronic obstructive lung disease, raised haematocrit and white blood cell counts, and the use of tobacco., ${ }^{2,3}$ Acute intraoperative blood loss and ocular surgery have also been associated with the development of NAION. ${ }^{4,5}$ The reported frequency of second eye attacks varies in the literature. Although Beck et al. ${ }^{6}$ found a low incidence, an incidence of $35 \%^{7}$ to $40 \%^{8,9}$ is generally accepted. No systemic risk factor has yet been found to be associated with the involvement of the second eye. ${ }^{3,7}$

Discs that are crowded with small physiological excavations are at increased risk for the eventual development of ischaemic optic neuropathy. ${ }^{10-12}$ Such optic nerve head appearance has been termed 'the disc at risk'. ${ }^{13}$

The Heidelberg retinal flowmeter (HRF) is used to measure perfusion in peripapillary and optic disc capillary beds. The HRF utilises a low-intensity infrared laser beam that scans the fundus. Red blood cells in motion strike the beam, causing some of the reflected light to be Doppler shifted. These shifts are analysed to determine their velocities. The amplitude of the shifts determines the volume of moving blood. Velocity and volume information permit computation of total blood flow. Thus, a map of flow values in the peripapillary area and retina may be drawn. ${ }^{14}$

The object of the present study was to determine whether there are specific patterns of blood flow in the optic nerve head in the as yet unaffected eye that can be used to identify the disc at risk.

\section{Patients and methods}

The study group comprised 14 patients with unilateral NAION diagnosed at the Kaplan Medical Center, Rehovot, Israel. The diagnosis of NAION was based on: (i) acute painless unilateral loss of vision, (ii) an ipsilateral relative afferent pupillary defect, (iii) optic-discrelated visual field defect, (iv) optic disc oedema, and (v) absence of clinical and laboratory evidence of arteritis. Patients were 


\begin{tabular}{|c|c|c|c|c|c|c|c|c|c|c|c|c|c|}
\hline $\begin{array}{l}\text { Patient } \\
\text { no. }\end{array}$ & $\begin{array}{c}\text { Age } \\
\text { (years) }\end{array}$ & Sex & $\begin{array}{l}\text { Affected } \\
\text { eye } \\
\text { (RE/LE) }\end{array}$ & $\begin{array}{l}\text { Visual } \\
\text { acuity } \\
\text { (BCVA) }\end{array}$ & Visual field & $\begin{array}{l}\text { Fellow eye } \\
\text { appearance }\end{array}$ & Hypertension & $\begin{array}{l}\text { Diabetes } \\
\text { mellitus }\end{array}$ & $\begin{array}{l}\text { Other } \\
\text { systemic } \\
\text { disease }\end{array}$ & Medication & Imaging & $\begin{array}{l}\text { Cardiac } \\
\text { echo }\end{array}$ & $\begin{array}{l}\text { Carotid } \\
\text { duplex }\end{array}$ \\
\hline 1 & 59 & $\mathrm{~F}$ & $\mathrm{RE}$ & $6 / 24$ & Superior altitudinal & Crowded disc & No & No & Asthma & Ventolin & $\begin{array}{l}\text { MRI-NL } \\
\text { CT-NL }\end{array}$ & ND & NL \\
\hline 2 & 67 & M & $\mathrm{RE}$ & $6 / 6$ & Inferior altitudinal & Crowded disc & Yes & yes & No & $\begin{array}{l}\text { Aspirin, } \\
\text { glibenclamide }\end{array}$ & CT-NL & NL & NL \\
\hline 3 & 57 & M & $\mathrm{RE}$ & $6 / 10$ & Superior altitudinal & Crowded disc & No & No & No & None & ND & NL & NL \\
\hline 4 & 81 & M & $\mathrm{RE}$ & $6 / 9$ & Superior altitudinal & Crowded disc & Yes & No & No & ACE inhibitor & ND & ND & NL \\
\hline 5 & 67 & M & $\mathrm{RE}$ & $6 / 30$ & Inferior altitudinal & Crowded disc & No & No & Arrhythmia & None & ND & ND & NL \\
\hline 6 & 50 & M & $\mathrm{RE}$ & $6 / 7.5$ & $\begin{array}{l}\text { Incomplete inferior } \\
\text { altitudinal }\end{array}$ & C/D 0.1 & No & Yes & None & & ND & ND & ND \\
\hline 7 & 58 & $\mathrm{~F}$ & $\mathrm{RE}$ & $6 / 60$ & Inferior altitudinal & C/D 0.4 & Yes & Yes & No & $\begin{array}{l}\text { Aspirin, diuretics, } \\
\beta \text {-blocker, ACE } \\
\text { inhibitor }\end{array}$ & ND & ND & NL \\
\hline 8 & 71 & M & $\mathrm{RE}$ & $6 / 7.5$ & Inferior altitudinal & C/D 0.4 & No & No & No & None & ND & ND & ND \\
\hline 9 & 60 & $\mathrm{~F}$ & LE & $6 / 60$ & Inferior altitudinal & Crowded disc & Yes & No & $\begin{array}{l}\text { Hyperchol- } \\
\text { esterolaemia }\end{array}$ & Aspirin & $\begin{array}{l}\text { CT-NL } \\
\text { MRI-NL }\end{array}$ & NL & NL \\
\hline 10 & 54 & $\mathrm{~F}$ & $\mathrm{RE}$ & $6 / 12$ & Superior nasal defect & Crowded disc & No & No & No & None & $\begin{array}{l}\text { CT-NL } \\
\text { MRI-NL }\end{array}$ & NL & NL \\
\hline 11 & 68 & $\mathrm{~F}$ & LE & $6 / 30$ & Superior altitudinal & C/D 0.4 & Yes & Yes & $\mathrm{IHD}, \mathrm{CHF}$ & $\begin{array}{l}\text { Glibenclamide, } \\
\text { aspirin, diuretics, } \\
\text { nitrates, } \mathrm{Ca}^{2+} \\
\text { antagonist, } \\
\text { simvastatin, ACE } \\
\text { inhibitor }\end{array}$ & $\mathrm{CT}-\mathrm{NL}$ & NL & NL \\
\hline 12 & 68 & M & $\mathrm{RE}$ & HM & Not done & C/D 0.6 & Yes & No & No & $\begin{array}{l}\beta \text {-blocker, diuretics, } \\
\text { ACE inhibitor }\end{array}$ & CT-NL & NL & NL \\
\hline 13 & 73 & $\mathrm{~F}$ & $\mathrm{RE}$ & $6 / 12$ & Inferior nasal defect & C/D 0.2 & Yes & No & No & Diuretics, $\beta$-blocker & ND & NL & NL \\
\hline 14 & 76 & $\mathrm{~F}$ & $\mathrm{RE}$ & $6 / 60$ & Inferior altitudinal & Crowded disc & Yes & Yes & No & $\mathrm{Ca}^{2+}$ antagonist & ND & NL & NL \\
\hline
\end{tabular}

$\mathrm{BCVA}$, best corrected visual acuity; C/D, cup-disc ratio; ND, not done; NL, normal; IHD, ischaemic heart disease; $\mathrm{CHF}$, congestive heart failure

${ }^{a}$ Hypertension defined as blood pressure $140 / 90 \mathrm{mmHg}$ or higher. ${ }^{17}$ 
excluded from the study if: (i) NAION had been diagnosed more than 6 months before the study was initiated, (ii) there was any disease or anomaly of the fellow eye, or (iii) they were unable to perform the test.

A detailed medical history was taken from all patients. Attention was paid to vascular disorders that may have an effect on ocular blood flow, such as arterial hypertension, diabetes mellitus, ischaemic heart disease, hypercholesterolaemia and arrhythmia. Whenever a thrombotic disease was suspected, the patient was sent for Doppler studies and cardiac echoes. Each patient underwent a complete neuro-ophthalmic examination and blood flow measurement of both optic nerve heads. The HRF, ${ }^{14}$ a confocal scanning laser Doppler flowmeter, was used for the measurement (in arbitrary units) of three haemodynamic variables: blood flow, volume and velocity. The parameters were computed after selecting square frames of $10 \times 10$ pixels on the HRF monitor, over the upper and lower temporal rims of the optic nerve head, using a $10^{\circ} \times 2.5^{\circ}$ thin rectangular slice of tissue. ${ }^{14}$

The HRF measurements mostly reflect the circulation within the nerve fibre layer. ${ }^{15}$ The anterior optic nerve head is mostly supplied with blood from the central retinal artery. However, changes in this layer may reflect changes in blood flow deeper within the nerve head. ${ }^{16}$

Comparisons were made between the unaffected and affected eyes, between the unaffected fellow eyes and the healthy control eyes, and between the affected eyes and the healthy control eyes. The control group consisted of 14 eyes of 7 healthy age-matched volunteers. When any systemic disease was suspected, and if blood pressure was recorded to be more than $140 / 90 \mathrm{mmHg}$, the volunteer was excluded from the study. ${ }^{17}$ Statistical analysis was carried out using Student's $t$-test. A $p$ value of $<0.05$ was considered significant.

\section{Results}

Data obtained from the patients are summarised in Table 1. The HRF measurements are summarised in Fig. 1, and the blood flow measurements in Tables 2-4.

Table 2. Blood flow measurements of all patients

\begin{tabular}{|c|c|c|c|}
\hline \multicolumn{2}{|c|}{ Lower rim } & \multicolumn{2}{|c|}{ Upper rim } \\
\hline $\begin{array}{l}\text { Affected } \\
\text { eyes }\end{array}$ & $\begin{array}{c}\text { Fellow } \\
\text { unaffected eyes }\end{array}$ & $\begin{array}{l}\text { Affected } \\
\text { eyes }\end{array}$ & $\begin{array}{c}\text { Fellow } \\
\text { unaffected eyes }\end{array}$ \\
\hline 138.73 & 270.93 & 142.31 & 252.61 \\
\hline 57.43 & 219.27 & 38.46 & 163.77 \\
\hline 158.54 & 324.52 & 155.58 & 342.36 \\
\hline 172.75 & 186.31 & 215.93 & 151.87 \\
\hline 155.46 & 490.75 & 157.57 & 240.29 \\
\hline 150.29 & 159.68 & 129.43 & 105.10 \\
\hline 258.91 & 413.53 & 272.92 & 289.65 \\
\hline 146.34 & 245.97 & 154.14 & 204.90 \\
\hline 137.13 & 258.73 & 153.18 & 274.16 \\
\hline 141.84 & 223.31 & 133.77 & 219.55 \\
\hline 355.74 & 483.40 & 258.94 & 373.21 \\
\hline 361.53 & 181.09 & 261.04 & 215.81 \\
\hline 234.66 & 183.05 & 218.31 & 137.38 \\
\hline 150.30 & 196.35 & 135.65 & 125.73 \\
\hline
\end{tabular}

Table 3. Blood flow measurements of the control eyes

\begin{tabular}{cc}
\hline Lower rim & Upper rim \\
\hline 448.06 & 563.95 \\
474.03 & 490.23 \\
270.79 & 304.52 \\
346.61 & 365.88 \\
360.11 & 353.36 \\
358.13 & 334.44 \\
359.39 & 384.89 \\
360.90 & 361.70 \\
455.94 & 347.86 \\
456.95 & 371.48 \\
390.18 & 348.02 \\
381.45 & 181.85 \\
264.00 & 234.31 \\
281.95 & 207.91 \\
\hline
\end{tabular}

Ocular blood flow in the affected eyes of patients in the study group differed significantly from that in the unaffected fellow eyes. The mean flow in the affected eyes, measured in arbitrary units (AU), was $187.12 \pm 86.0$ $\mathrm{AU}$ and $173.37 \pm 64.55 \mathrm{AU}$ for the lower and upper rim, respectively, compared with $274.06 \pm 112.02 \mathrm{AU}$ and $221.17 \pm 80.69$ AU in the unaffected eyes $(p<0.025$ and $p<0.05$ for the lower and upper rim, respectively.

There was also a significant difference in mean blood flow between the affected eyes of patients with NAION and the eyes of the healthy controls $(187.12 \pm 86.0 \mathrm{AU}$ and $173.37 \pm 64.55 \mathrm{AU}$ in the affected eyes for the lower and upper rim, respectively, compared with $372.03 \pm 69.14 \mathrm{AU}$ and $346.45 \pm 100.57 \mathrm{AU}$ in the controls; $p<0.00005$ for both the lower and upper rims). A comparison between the unaffected fellow eyes and the control eyes also yielded significant differences. The mean flow at the lower rim was $274.06 \pm 112.02 \mathrm{AU}$ for the unaffected fellow eyes and 372.03 \pm 69.14 AU for the controls $(p<0.005)$. The corresponding values at the upper rim were $22.17 \pm 80.69 \mathrm{AU}$ and $346.45 \pm 100.57$ AU for the controls $(p<0.005)$. The flow was lower in the upper rim than in the lower rim in most of the tested eyes but the difference was not significant. There were no differences in mean blood flow measurements between the fellow eyes of the controls.

Two patients (nos. 2 and 10, Table 1) developed NAION in the unaffected fellow eye during the study, 3 and 4 months respectively after the attack in the first eye. The flow measurements in these 2 patients are summarised in Table 5. The mean blood flow in the second eye in both cases was lower than the average flow of all the unaffected fellow eyes.

Table 4. Blood flow (average \pm SD) measurements (in arbitrary units) of affected eyes, fellow unaffected eyes and controls

\begin{tabular}{llcc}
\hline & Affected eyes & $\begin{array}{c}\text { Unaffected } \\
\text { fellow eyes }\end{array}$ & Controls \\
\hline Lower rim & $187.12 \pm 86.0$ & $274.06 \pm 112.02$ & $372.03 \pm 69.14$ \\
Upper rim & $173.37 \pm 64.55$ & $221.17 \pm 80.69$ & $346.45 \pm 100.57$ \\
\hline
\end{tabular}


a.

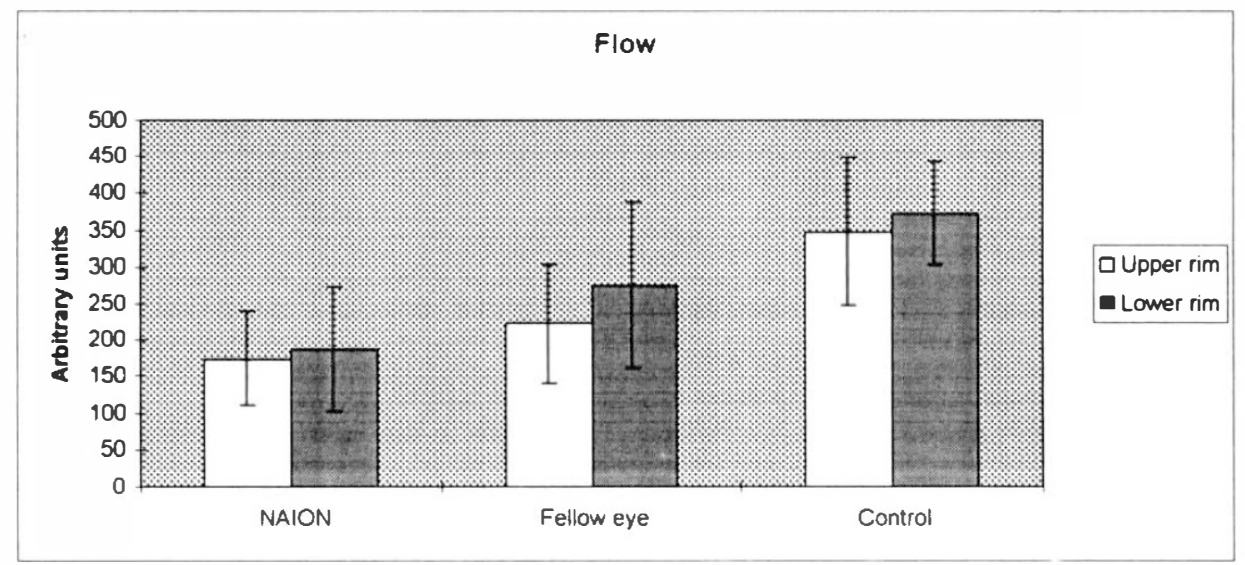

b.

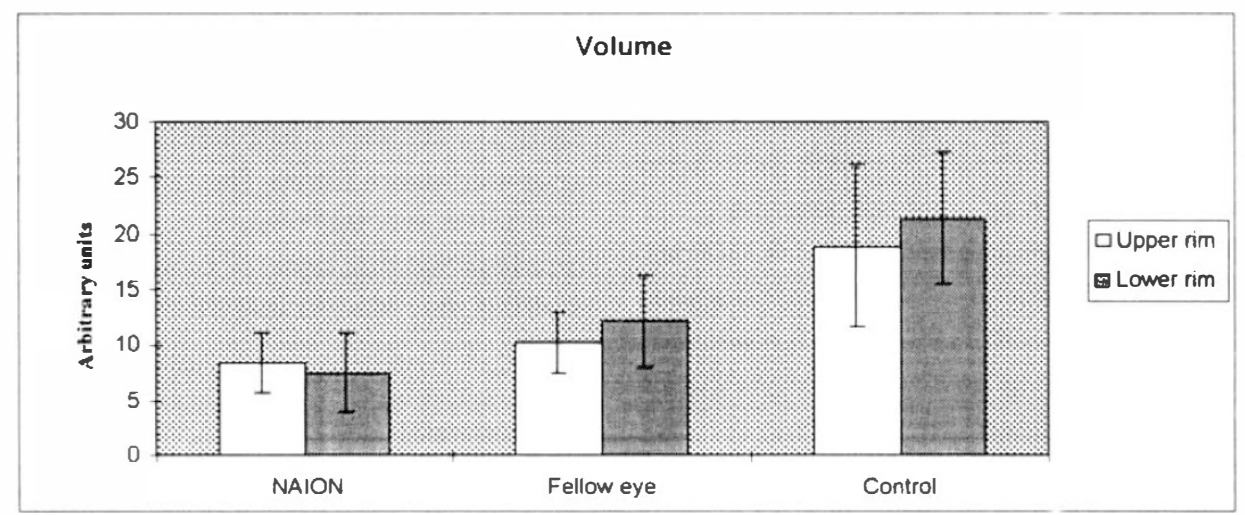

c.

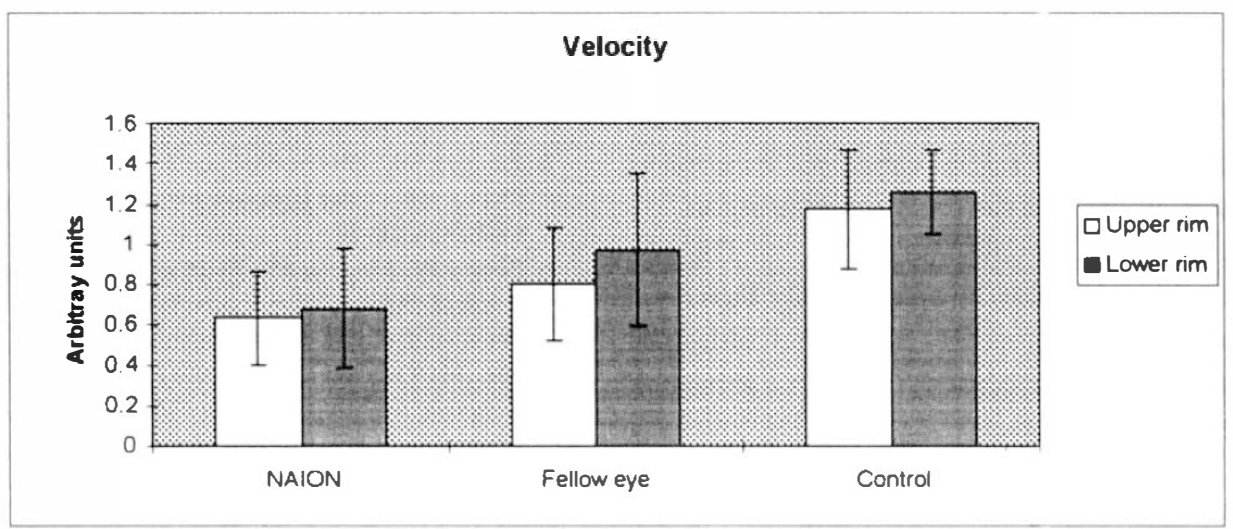

Fig. 1. Average measurement of blood flow (a), volume $(b)$ and velocity $(c)$ in the upper and lower rims of 14 eyes with NAION, 14 unaffected fellow eyes, and 14 healthy eyes of 7 controls.

\section{Discussion}

The results of this study show that the blood flow, volume and velocity in the unaffected eyes of patients with unilateral NAION were significantly lower than in the eyes of healthy controls. There was no correlation between blood flow measurements and optic disc appearance, possibly suggesting the presence of another risk factor for development of NAION.

The pathogenesis of NAION is unclear. The available evidence points to disturbances in blood flow of the optic 
Table 5. Blood flow measurements (arbitrary units) in patients 2 and 10 compared with the average flow of all patients and controls

\begin{tabular}{|c|c|c|c|c|c|c|c|}
\hline & \multicolumn{2}{|c|}{ Patient 2} & \multicolumn{2}{|c|}{ Patient 10} & \multicolumn{2}{|c|}{ Average, all patients } & \multirow{2}{*}{$\frac{\text { Average, control }}{\text { Both eyes }}$} \\
\hline & Affected eye & Fellow eye & Affected eye & Fellow eye & Affected eye & Fellow eye & \\
\hline Lower rim & 154.14 & 245.97 & 150.29 & 159.70 & $187.12 \pm 86.0$ & $274.06 \pm 112.02$ & $372.03 \pm 69.14$ \\
\hline Upper rim & 146.34 & 204.90 & 129.43 & 105.10 & $173.37 \pm 64.55$ & $221.17 \pm 80.69$ & $346.45 \pm 100.57$ \\
\hline
\end{tabular}

nerve head as the primary factor. ${ }^{12,16,18,19}$ Fluorescein angiographic studies of arteritic patients show delayed choroidal filling, as well as segmental filling defects of the peripapillary choroid and adjacent optic disc. ${ }^{16,20}$ In patients with NAION there were significant delays in the filling of the prelaminar optic nerve head, but no delay in onset of filling of the peripapillary choroid. ${ }^{16,20}$ These findings suggest that the impaired disc perfusion in NAION does not result from occlusion of the short posterior ciliary arteries or from a hypoperfused peripapillary choroid, as in arteritic AION, but from blood flow disturbances within the optic nerve head itself. ${ }^{16,18}$

The clinical characteristics of ischaemic optic neuropathy suggest that this is a vascular disease. The term 'NAION' is reserved for cases in which there is no clear aetiological factor, such as giant cell arteritis. Various conditions have been suggested as risk factors for NAION. ${ }^{7,21}$ However, none of these systemic diseases is unequivocally associated with NAION, and, moreover, in most of the studies there was no evidence of associated systemic disease in about $30 \%$ of the patients.

According to Hayreh, the pathogenesis of NAION is multifactorial and the structure of the optic disc is an important factor. ${ }^{12,22}$ The characteristics of a disc that may predispose an individual to the development of NAION include a small optic nerve head with a small or absent physiological cup, abnormal branching pattern of the central retinal vessels, and a lush layer of nerve fibres elevating the disc margins. ${ }^{10-13}$ This appearance causes crowding of the optic nerve fibres within the scleral canal. A change in blood flow, failure of autoregulation, or both, may cause axoplasmic stasis. ${ }^{23}$ Swelling of the nerve fibres crowded in the scleral canal will compress the blood vessels among the nerve fibres, leading to further ischaemia and eventually an infarct. ${ }^{12,24}$ The crowding in itself is undoubtedly not the only factor causing this cascade. It was recently stated that 'although rare, NAION can occur in an optic nerve with a generous cup $^{\prime 25}$ In our series of 14 patients with NAION, four had a cup-disc (C/D) ratio of 0.4 or more in the fellow eye, and one of them had a documented C/D ratio of 0.7 prior to the development of NAION (patients 7, 8, 11 and 12, Table 1).

In a nerve with an initially low blood flow, any insult such as a decrease in blood pressure may precipitate an ischaemia that will cause axonal swelling. According to this assumption, crowded discs with diminished blood flow would be at higher risk for the development of NAION. Two of our patients developed NAION in the second eye during the course of the study, both had crowded discs and blood flow measurements that were lower than the average flow of the fellow unaffected eyes in this group.

Both in the unaffected fellow eyes and in the controls, blood flow in the upper rim of the optic nerve head was lower (though not significantly so) than in the lower rim. This may indicate a zone of susceptibility to infarction and, though not proven, may explain the observation that the superior part of the optic disc is more commonly involved than the inferior part, and that inferior altitudinal field defects are more common. ${ }^{10,26,27}$

Though conclusions from such a small sample size should be drawn with caution, our findings support the theory that the structure of the optic disc has a role in the pathogenesis of NAION, and add a suggestion that the 'disc at risk' has a low blood flow that is unrelated to the crowded nerve fibres. The trigger event for NAION is still unknown, but when it occurs in an optic disc that is predisposed due to nerve crowding or low blood flow, or both, it may lead to infarction.

\section{References}

1. Miller NR. Anterior ischemic optic neuropathy. In: Walsh and Hoyt's clinical neuro-ophthalmology. 4th edn. Baltimore: Williams \& Wilkins, 1982:217-9.

2. Jacobson DM, Vierkant RA, Belongia EA. Nonarteritic anterior ischemic optic neuropathy. Arch Ophthalmol 1997;115:1403-7.

3. Salomon O, Huna-Baron R, Kurtz S, et al. Analysis of prothrombotic and vascular risk factors in patients with nonarteritic anterior ischemic optic neuropathy. Ophthalmology 1999;106:739-42.

4. Jaben SL, Glaser JS, Daily M. Ischemic optic neuropathy following general surgical procedures. J Clin Neuroophthalmol 1983;3:239-44.

5. Hayreh SS. Anterior ischemic optic neuropathy. IV. Occurrence after cataract extraction. Arch Ophthalmol 1980;98:1410-6.

6. Beck RW, Hayreh SS, Podhajsky PA, Tan E-S, Moke PS. Aspirin therapy in nonarteritic anterior ischemic optic neuropathy. Am J Ophthalmol 1973;123:212-7.

7. Beri M, Klugman MR, Kohler JA, Hayreh SS. Anterior ischemic optic neuropathy. VII. Incidence of bilaterality and various influencing factors. Ophthalmology 1987;94:1020-8.

8. Boghen DR, Glaser JS. Ischaemic optic neuropathy: the clinical profile and natural history. Brain 1975;98:689-708.

9. Hayreh SS, Podhajsky P. Visual field defects in anterior ischemic optic neuropathy. Doc Ophthalmol Proc Ser 1979;19:53-71.

10. Hoyt WF. Unpublished data presented at the Rocky Mountain Neuro-Ophthalmologic Society Meeting, 1982.

11. Beck RW, Savino PJ, Repka MX, Schatz NJ, Sergott RC. Optic disc structure in anterior ischemic optic neuropathy. Ophthalmology 1984;91:1334-7.

12. Beck RW, Servais GE, Hayreh SS. Anterior ischemic optic neuropathy. IX. Cup-to-disc ratio and its role in pathogenesis. Ophthalmology 1987;94:1503-8. 
13. Burde RM. Optic disc risk factors for nonarteritic anterior ischemic optic neuropathy. Am J Ophthalmol 1993;116:759-64.

14. Kagemann L, Harris A, Chung HS, Evans D, Buck S, Martin B. Heidelberg retinal flowmetry: factors affecting blood flow measurement. Br J Ophthalmol 1998;82:131-6.

15. Wang L, Cioffi GA, Van Buskirk EM, Zaho D-Y, Bacon DR. Comparison of optic nerve blood flow measured with laser Doppler flowmetry and microspheres. Invest Ophthalmol Vis Sci 1999;40:S276.

16. Arnold AC, Hepler RS. Fluorescein angiography in acute nonarteritic anterior ischemic optic neuropathy. Am J Ophthalmol 1994;117:222-30.

17. Kaplan NM. Clinical hypertension. 7th ed. Baltimore: Williams \& Wilkins, 1998:1-2.

18. Lessell S. Nonarteritic anterior ischemic optic neuropathy. Enigma variations. Arch Ophthalmol 1999;117:386-8.

19. Landau K, Winterkorn JMS, Mailloux LU, Vetter W, Napolitano B. 24-Hour blood pressure monitoring in patients with anterior ischemic optic neuropathy. Arch Ophthalmol 1996;114:570-5.

20. Siatkowski RM, Gass DM, Glaser JS, Lawton Smith J, Schatz NJ, Schiffman J. Fluorescein angiography in the diagnosis of giant cell arteritis. Am J Ophthalmol 1993;115:57-63.
21. Hayreh SS, Jool KM, Podhajsky PA, Long CR. Systemic diseases associated with nonarteritic anterior ischemic optic neuropathy. Am J Ophthalmol 1994;118:766-80.

22. Hayreh SS. Anterior ischemic optic neuropathy. V. Optic disc edema an early sign. Arch Ophthalmol 1981;99:1030-40.

23. McLeod D, Marshall J, Kohner EM. Role of axoplasmic transport in the pathophysiology of ischaemic disc swelling. Br J Ophthalmol 1980;64:247-61.

24. Hayreh SS, Zimmerman MB, Podhajsky P, Alward WLM. Nocturnal arterial hypotension and its role in optic nerve head and ocular ischemic disorders. Am J Ophthalmol 1994;117:603-24.

25. Parsa CF, Muci-Mendoza R, Hoyt WF. Anterior ischemic optic neuropathy in a disc with a cup: an exception to the rule. J Neuro Ophthalmol 1998;18:169-70.

26. Repka MX, Savino PJ, Schatz NJ, Sergott RC. Clinical profile and long-term implications of anterior ischemic optic neuropathy. Am J Ophthalmol 1983;96:478-83.

27. Rizzo JF, Lessell S. Optic neuritis and ischemic optic neuropathy. Overlapping clinical profiles. Arch Ophthalmol 1991;109:1668-72. 